\title{
THE UKRAINIAN EMPLOYERS' EXPERIENCE OF INTRODUCING DUAL STUDIES: THE FIRST-YEAR RESULTS OF THE NATIONAL EXPERIMENT
}

\author{
Olena Buchynska, Olena Davlikanova, and Iryna Lylyk
}

\begin{abstract}
The transition to the knowledge-based economy emphasizes the need of bridging the gap between the employers' needs and expectations with regard to their employees' knowledge and skills and the existing level of the knowledge and skills of the workforce, including the graduates of tertiary educational establishments (TEEs). One of the instruments that has already proven its efficiency in "building bridges" between the companies and higher educational institutions is dual studies (DS). Companies view such cooperation as the investment in its competitiveness, which, in its turn, is viewed as one of the factors of the national economic development. Thus, the Friedrich-Ebert-Stiftung Office in Ukraine (FESUkraine) launched a project aimed at presenting and adapting the experience of Germany in dual studies organization in 2013. As a result, in 2019, the Ministry of Education and Science of Ukraine (MES) launched a national experiment on introducing DS in 44 pre-tertiary and tertiary educational establishments. The article aims to present the results of the survey conducted among the Ukraine-based employers that participated in the first year of this experiment. The authors' questionnaire survey was carried out from June to September 2020. The respondents included 111 companies indicated as partners by the TEEs listed in the ministerial Order \#1296 on the launch of the experiment planned for the period of 2019-2023. The answers were obtained from 93 companies, 55 of which presented details of TEE-company cooperation. The data obtained allowed performing both quantitative and qualitative analysis. The findings show that companies are interested in dual studies and are ready to invest in training students as their potential employees. German approaches to the DS organization cannot be simply copied due to the specific features of the national legislation and the state of the national economy. However, they may be successfully adapted and implemented in Ukraine. Therefore, the obtained information has been used for elaborating recommendations to the stakeholders (TEEs, employers and their associations, the MES and other relevant state bodies etc.).

Keywords: dual higher education, dual form of education, dual studies, dual study models, dual tertiary education, Duales Studium, employers, higher educational institutions, human capital, Ministry of Education and Science of Ukraine, pilot project, students, tertiary education
\end{abstract}

JEL Classification: A20, M00 


\section{Authors:}

\section{Olena Buchynska}

Kiev National Economic University Kyiv, Ukraine

E-mail: elenabuchynska@gmail.com

https://orcid.org/0000-0003-2991-2110

\section{Olena Davlikanova}

Friedrich Ebert Foundation, Office in Ukraine, Kyiv, Ukraine

E-mail: elena100deals@gmail.com

https://orcid.org/0000-0001-8536-3959

\section{Iryna Lylyk}

President of the Ukrainian Marketing Association, Kyiv, Ukraine

E-mail:iryna.lylyk@kneu.ua

https://orcid.org/0000-0003-4748-5407

Citation: Buchynska, O., Davlikanova, O., \& Lylyk, I. (2020). The Ukrainian Employers' Experience of Introducing Dual Studies: The First-Year Results of the National Experiment. Virtual Economics, 3(4), 211-234. https://doi.org/10.34021/ve.2020.03.04(11) 


\section{Introduction}

Tertiary education (TE) is not only considered a pillar of human development, but also one of the engines of economic success of countries and individuals; and it becomes even more important in the XXI century, when throughout the world economy, more than ever, knowledge is becoming the major driver of production and innovation (World Bank, 2002; OECD, 2008; Council of the European Union, 2009). Decision-makers understand the need in responding to the global challenges and are looking for solutions in order to create conditions for increasing compatibility of national economies by means of investments in human capital. Thus, the EU countries have established objectives of reaching the common benchmark of $40 \%$ of the 30-34-year olds with a higher education or equivalent, viewing education and training as a driving force for creating jobs and economic growth, as well as a factor of sustainable development (European Commission, 2019a). And this trend is expected to continue (Figure 1).

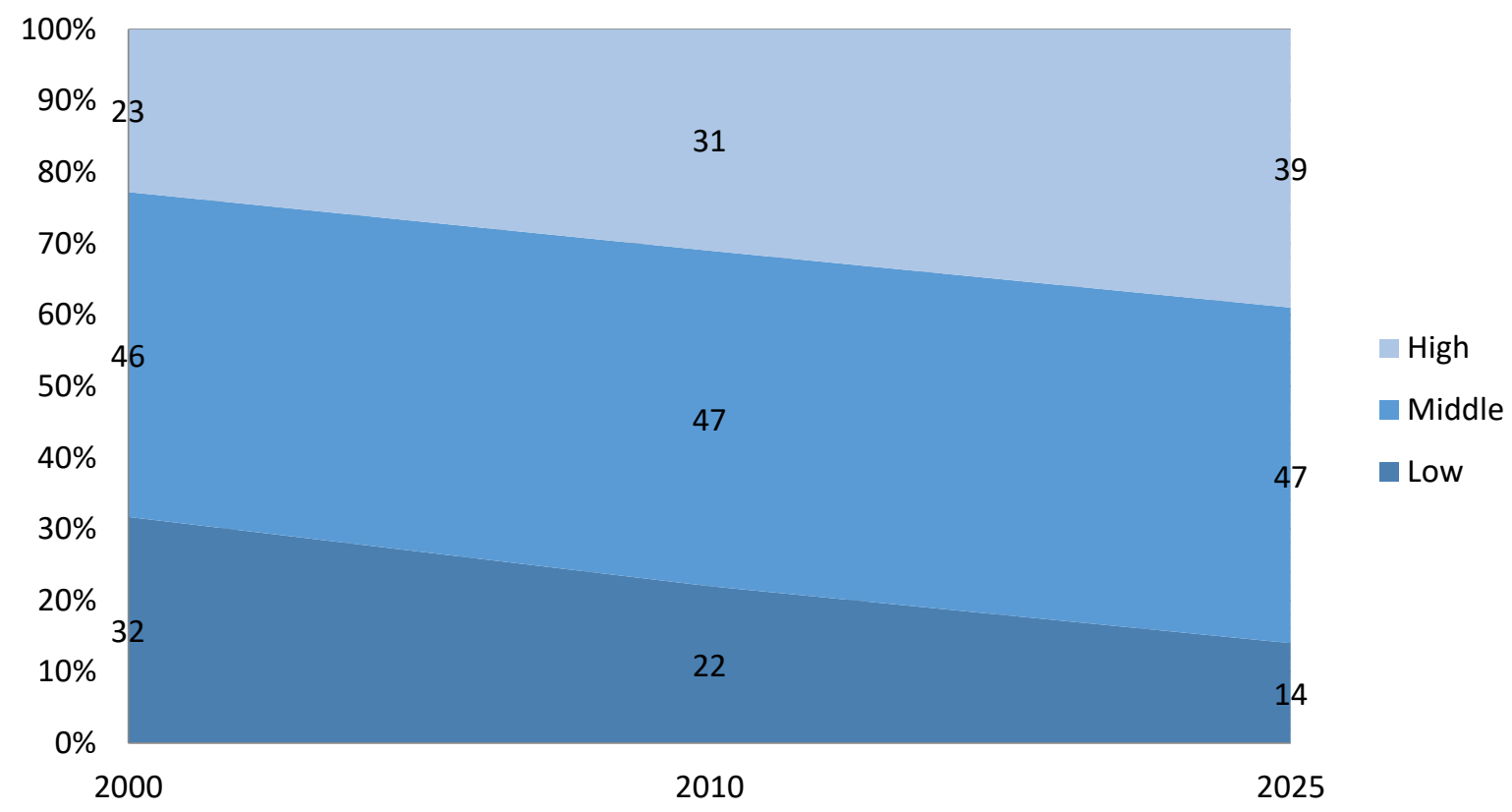

Figure 1. The Labor Force - a Share of Qualifications in the EU Countries, 2000-2025, a Baseline Scenario.

Source: (Cedefop, 2013).

One can never have excessive education and skills, thus, in some respects, they may be considered merit goods. It is rational for individuals to invest in their qualifications to ensure their competitiveness on the labor market and career prospects; likewise, an economy can never overinvest in its human capital, but only if the skills produced generate a return to those investing. (Dolphin, 2015). Thus, the balanced combination of theory and practice within curricula are essential for bridging the gap between the results of studies and the needs of employers as of graduates' qualifications. 
Due to the relatively mild influence of the world economic crises on the economy of the Federal Republic of Germany and the low level of unemployment among the youth in the country, in search for solutions more and more interested actors from abroad are paying attention to the dual education system, which foresees combination of at least two study places - an educational institution and a company (Graf, 2015; BiBB, 2020a; 2020b). Only 1\% of the graduates were unemployed a year and a half after completing a dual bachelor's degree in contrast to $6 \%$ of the graduates with a regular bachelor's degree. Dual study programs also ensure that qualifications and competencies acquired by students are needed by the employers. DS improves the school-to-work transition for young people and increases their chance for permanent employment (Hermann, 2020).

Though, such approach was first applied and later developed into the "export item" on the level of vocational education and training ("Duale Ausbildung"), in recent decades German higher education absorbs some features of the dual VET in the format of dual studies ("Duales Studium") (Wissenschaftsrat, 2013; BiBB, 2017; Hippach-Schneider et al., 2017).

Ukraine is one of those countries that has attempted to adapt German models of both dual VET education and dual studies to the national context (The Ministry of Education and Science of Ukraine, 2016; 2020a). Taking into account that young people in the age group of 15-24 are still pursuing their education, the age group of 25-29 (mostly graduates) are the group most vulnerable to unemployment with the higher than average numbers (Figure 2).

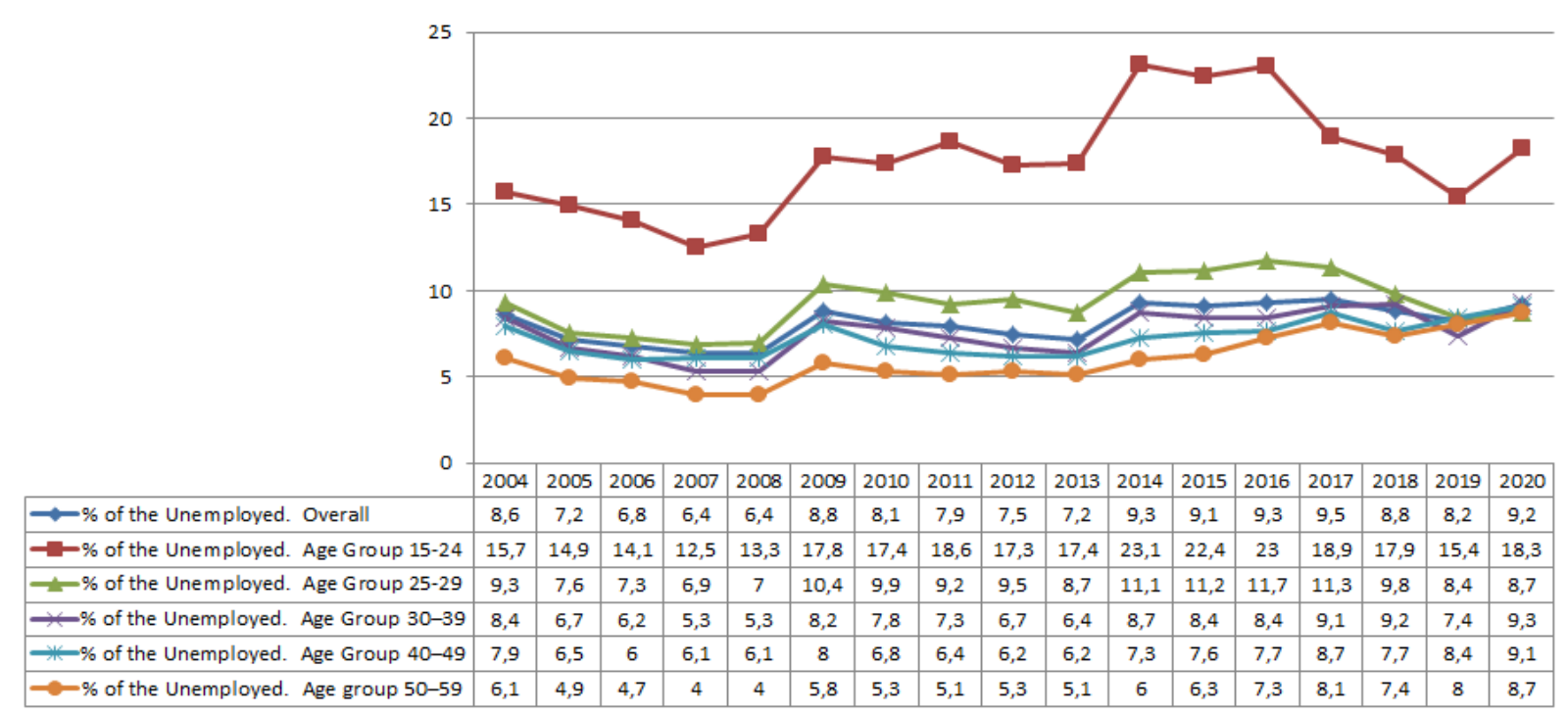

Figure 2. The Level of Unemployment in Ukraine, 2004-2020, by Age groups (\%)

Source: developed by Olena Davlikanova based on the State Statistic Service Data (2004-2020).

This article does not cover efforts aimed at introducing the dual VET but rather concentrates on dual tertiary education (dual studies). The impact of higher education on the life prospects 
of a person and the overall development of a country is undeniable. Individuals with higher education degree reported to have higher earnings over their lifetime and a better quality of life overall, as well as better understanding of civic issues and the world development trends (Chism et al., 2016), while for a country a bigger share of citizens with at least bachelor's degree correlates with lucrative community, a higher tax pool and overall global competitiveness. "For these reasons, higher education remains the best avenue to prosperity, opportunity, and a stronger nation."

In 2019 the MES launched a national experiment on introducing of dual studies in 44 pretertiary and tertiary educational establishments in partnership with a number of volunteering companies. The article presents information regarding the dual studies introduction experience of Ukraine-based employers gathered by the authors in the framework of one in the series of studies compiled for the Ministry of Education and Science of Ukraine (the MES). The first study was devoted to the experience of the pre-tertiary and tertiary educational establishments (Chaikovska et al., 2020); the second - of the employers involved into dual studies introduction experiment (Buchynska et al., 2020); and the third one - to the experience of the dual students (in-progress) (Figure 3).

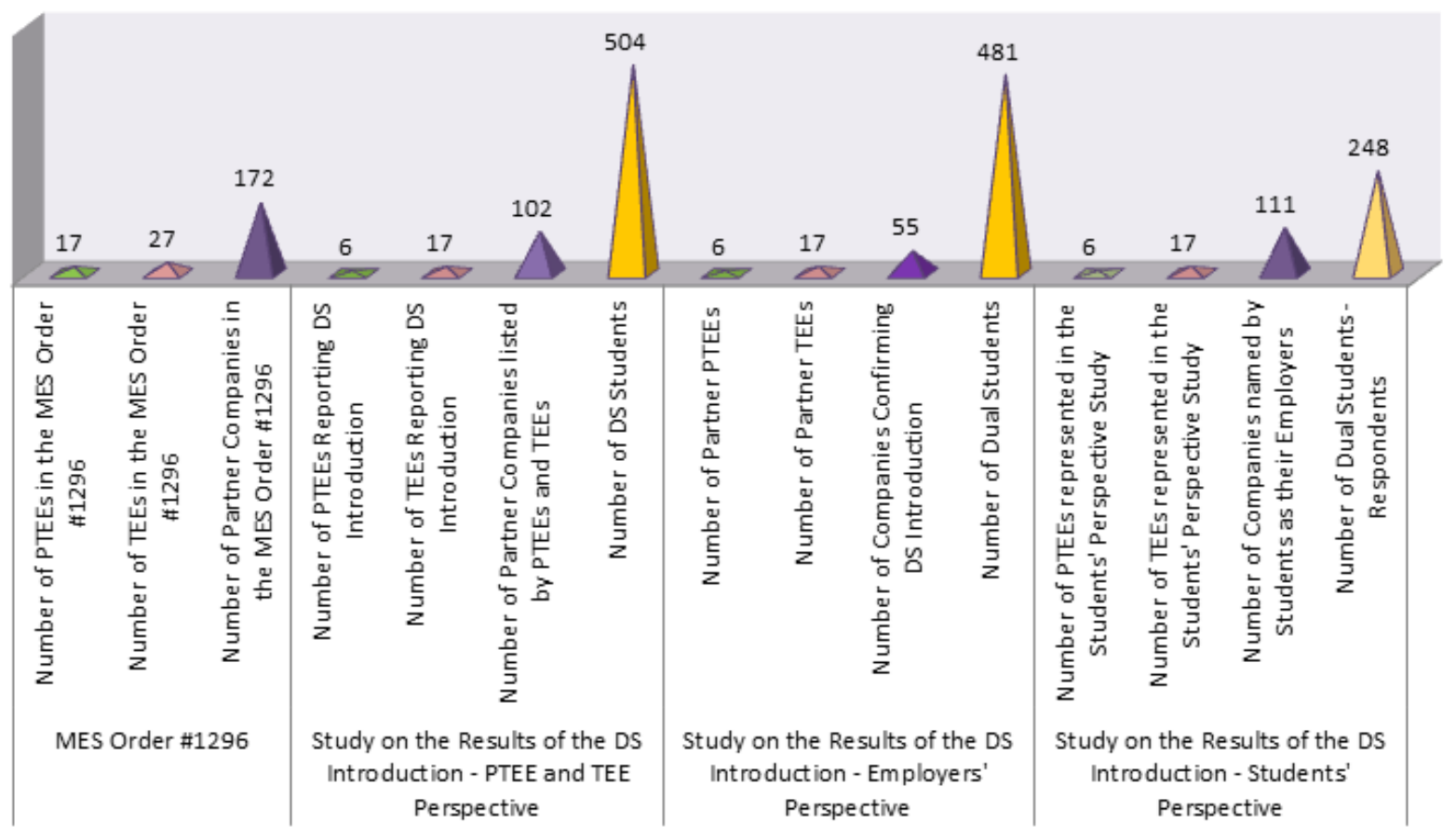

Figure 3. A Comparison of Quantitative Data Gathered in the Framework of studies Conducted among Educational Establishments and Employers during the First Year of the DS Introduction Experiment (2019-2020)

Source: developed by Olena Davlikanova based on the results of the "Analytical report on the 1st year of the DS Introduction - Educational Establishments' Perspective" (Chaikovska et al., 2020); the "Analytical report on the 1st year of the DS Introduction - Employers' Perspective" (Buchynska et al., 2020), and the "Analytical report on the 1st year of the DS Introduction - Students' Perspective".

The experiment is the result of the efforts by the Friedrich Ebert Foundation Office in Ukraine 
that in cooperation with local partners launched a project «Adaptation of Dual Studies Elements to the Ukrainian National Context» in 2013. During the whole period of its implementation, among such partners there were the Ministry of Education and Science of Ukraine, state and private educational establishments, companies, an NGO «Ukrainian Marketing Association", the Federation of Metallurgists of Ukraine, the Methodological Center for Pre-Tertiary and Tertiary Education etc. As a result, stakeholders compiled the Concept of the Dual Form of Education/Studies (The Ministry of Education and Science, 2018); amendments introducing dual studies were made to the Laws "On Education" and "On Higher Education" in 2018-2019; and as a final step, in 2019 the experiment on the introduction of the dual form of education in 17 pre-tertiary and 27 tertiary educational establishments was launched.

The Concept, as well as the efforts of the FES-Ukraine and partners was first concentrated on the dual higher education due to the abovementioned global trends. Only on the final stage the Concept, being a conceptual document, also included VET by the decision of MES. However, the following work was again divided into two separate directions - VET and tertiary education - due to a number of specific features in the organization of the education. In addition, the state and funding of Ukrainian VET and TE differ greatly, as well as their popularity among the youth and their parents (Figure 4).

The article aims to describe the main findings of the authors' survey among the Ukraine-based employers as of their experience in the framework of the first year of dual studies experiment. It includes four parts. The first part - the literature review - presents ideas of researchers and experts on the global megatrends impacting the nature of work, polarization of jobs, importance of education, especially tertiary education, as well as cooperation of educational establishments and business as a factor of ensuring high level of labor force qualifications as a prerequisite for the national economy development with the focus on the knowledge economy and changes on the labor market caused by the automation and digitalization; as well as the review of publications devoted to the dual studies in Germany and their adoption in other countries. The second part - methodology and research methods - outlines methods applied by the authors to conduct the survey among the employers enrolled into the dual studies experiment on the request by the Ministry of Education and Science of Ukraine. The third part - results and discussion - summarizes the main findings of the authors on the first year of dual studies experiment. The fourth part - conclusions - presents implications for further research of the initiatives aimed at the dual studies introduction. 
www.virtual-economics.eu

ISSN 2657-4047 (online)

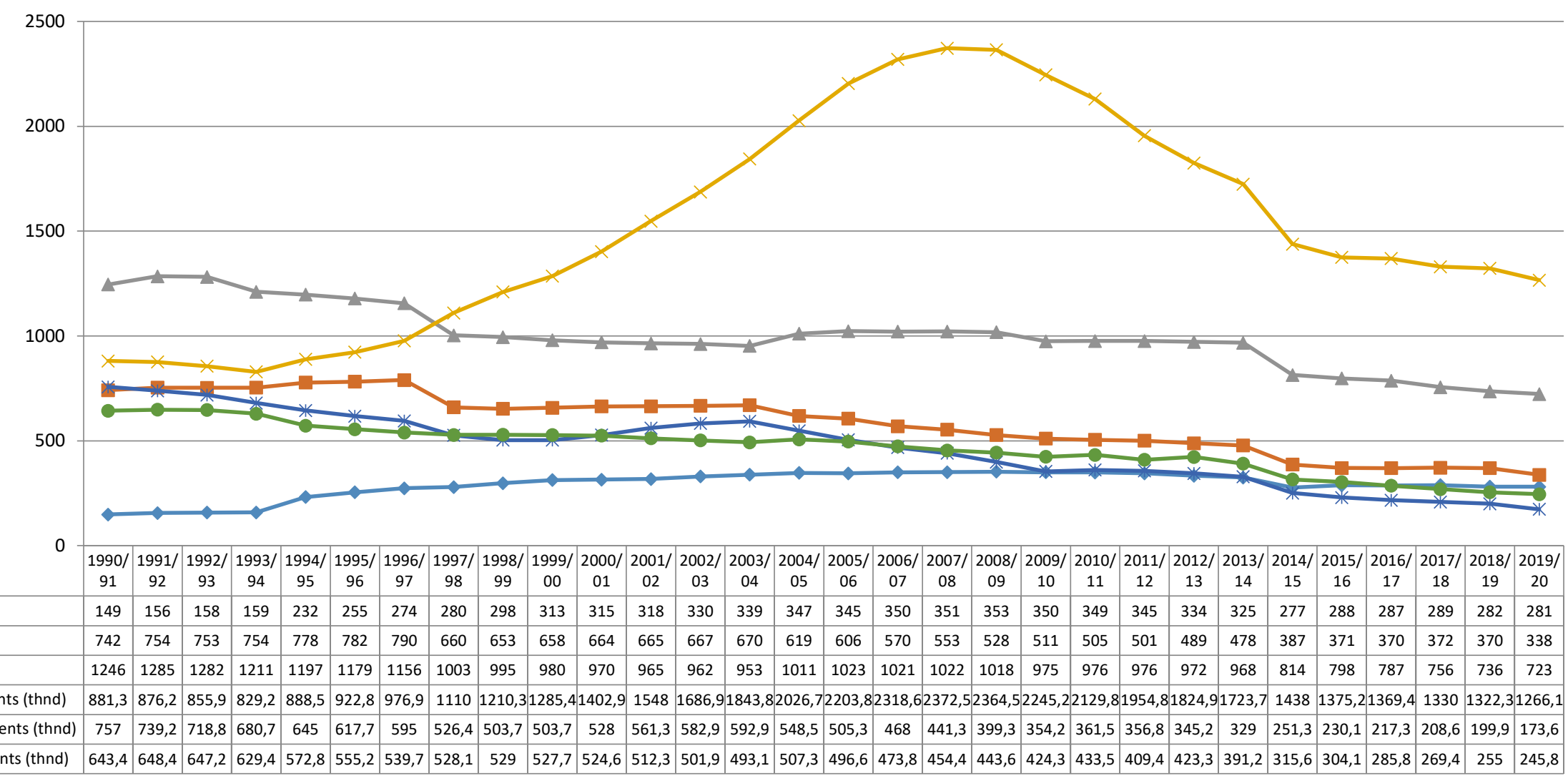

Figure 4. A Comparison of Ukrainian VET, Pre-Tertiary and Tertiary Education

Source: developed by the authors

Olena Buchynska, Olena Davlikanova, and Iryna Lylyk

Virtual Economics, Vol. 3, No. 4, 2020 


\section{The Literature Review}

Digital transformation, globalization and demographic changes are the megatrends of today shaping the landscape of a labor market through creating and destructing jobs as well as changing the nature of existing occupations and shaping skills demand. All this puts an unprecedented pressure on traditional education and training systems to provide opportunities for developing in-demand skills (ILO \& OECD, 2018). A number of studies worldwide projected significant changes in sectoral employment structures not only for the developed but even more for the transition countries, demonstrating "a shift away from simple and manufacturing activities towards knowledge-based and other consumer services" (Dach, 2013; Cedefop, 2016; Bakhshi et al., 2017; Tkachenko et al., 2019). The changes are so tangible that even 'elementary' jobs that usually required no or low-level qualifications are becoming more complex (Cedefop, 2013).

The pattern of the demand for labor force with higher-level formal qualifications, including a university degree, has existed for some time already. However, polarization within the labor market is expected to continue till 2030 and beyond, which results in significant raise in opportunities for high-skill occupations and some growth of the number of the low skilled jobs, while the medium-skill occupations are those in danger of extinction. Yet, growth of employment at the bottom of the wage distribution will not contribute to the individuals' welfare (Cedefop, 2013, 2018) (Figure 5).

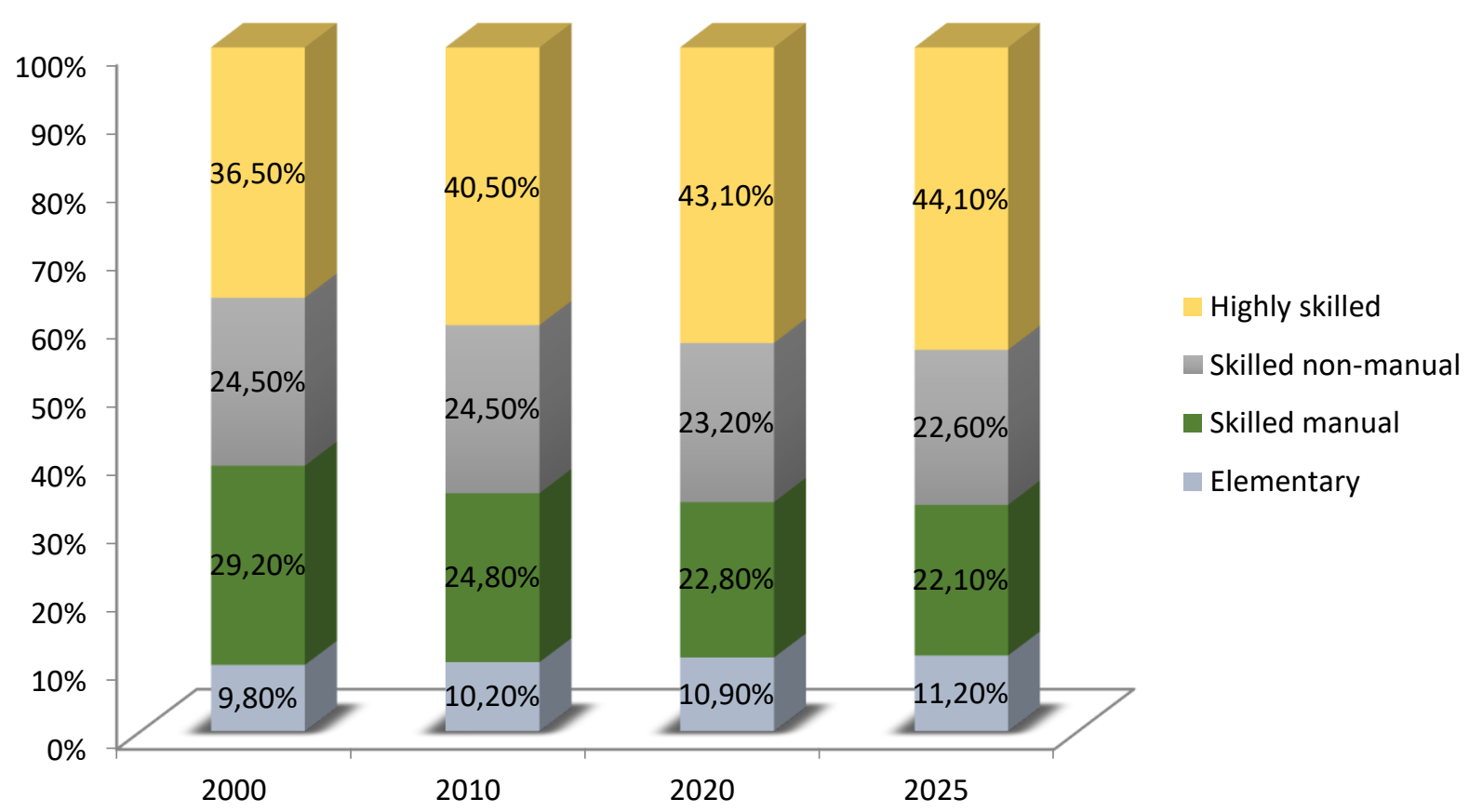

Figure 5. An Employment Share by the Skill Level in the EU, 2000-2025, Baseline Scenario (\%) Source: (Cedefop, 2013). 
When assessing trends in skills needed, it is not enough to consider the qualification level required for a job, but also how complex or routine it is becoming (Cedefop, 2013). Researchers emphasize the impact of the 'routine-biased technological change' or job polarization, when demand for routine jobs and tasks (no matter if of a cognitive or manual character) is falling considerably (Card \& DiNardo, 2002). Though, not all routine tasks can be automated, in a number of cases, instead of replacing entire jobs, tasks within occupations are becoming more technology-intensive. However, this trend also favors higher education. Though, HE does not give immunity against unemployment or loss of a job to automation, but it gives way to less automatable jobs. It is projected that the more general problem-solving skills, which are taught at higher education establishments, will not only be more demanded on the labor market, but will also provide a wider range of opportunities for re-qualification; while the occupation-specific skills imparted by vocational training tend to become obsolete faster. Those with vocational training are more likely to be working in an automatable job than those with a university degree or may find themselves shifting from one precarious job to another with no prospects for a better future (ILO, 2017). According to some estimations, tertiary education reduces the risk of losing a position for automation by 8.6 percentage points in low- and middle-income countries and 8.8 percentage points in OECD countries; on the other hand, vocational training increases such risk by 2.3 and 2.5 percentage points respectively (ILO \& OECD, 2018). Moreover, a rise in the demand for highly skilled workers leads to a rise in earnings inequality. The low- and high-skilled occupations are classified based on the average wage over the period 1997-2013; the difference between these two groups is around $130 \%$. Though the wage structure cannot be easily explained, the phenomenon should be studied in more detail (Card \& DiNardo, 2002; Haskel \& Slaughter, 2002). In addition, as of the access of high-skilled labor force to better paid jobs, according to some assumptions, trans-national enterprises, which are more productive due to possessing unique technologies and knowledge of production methods, and pay higher wages, will enjoy more skilled employees due to reduction of routine- and low-skilled job tasks, while local and smaller companies will hire routine- and low-skilled employees (Heyman \& Sjöholm, 2019) (Figure 6).

The young people and the low-skilled workers are the most vulnerable groups with regard to the occurring changes on the labor market (OECD, 2019). The youth continue to be overrepresented among the unemployed, while among those employed most currently young people have jobs of poor quality characterized by precarious working conditions, absence of legal and social protection, little or no opportunities for training and career prospects, and low wages. Though they see opportunities in the "Fourth Industrial Revolution", they also tend to worry about possible loss of their current or potential jobs to robots and artificial intelligence (ILO, 2017). Skill obsolescence is defined as the "degree to which professionals lack the up-todate knowledge or skills necessary to maintain effective performance in their current or future work roles" (Kaufman, 1974). Technological progress has always been a reason of skill obsolescence; however, Industry 4.0 and the current changes on the labor market, including the raise of the number of more demanding jobs, place the economic skill obsolescence and issues of education and training on top of the agenda (Cedefop, 2012). 


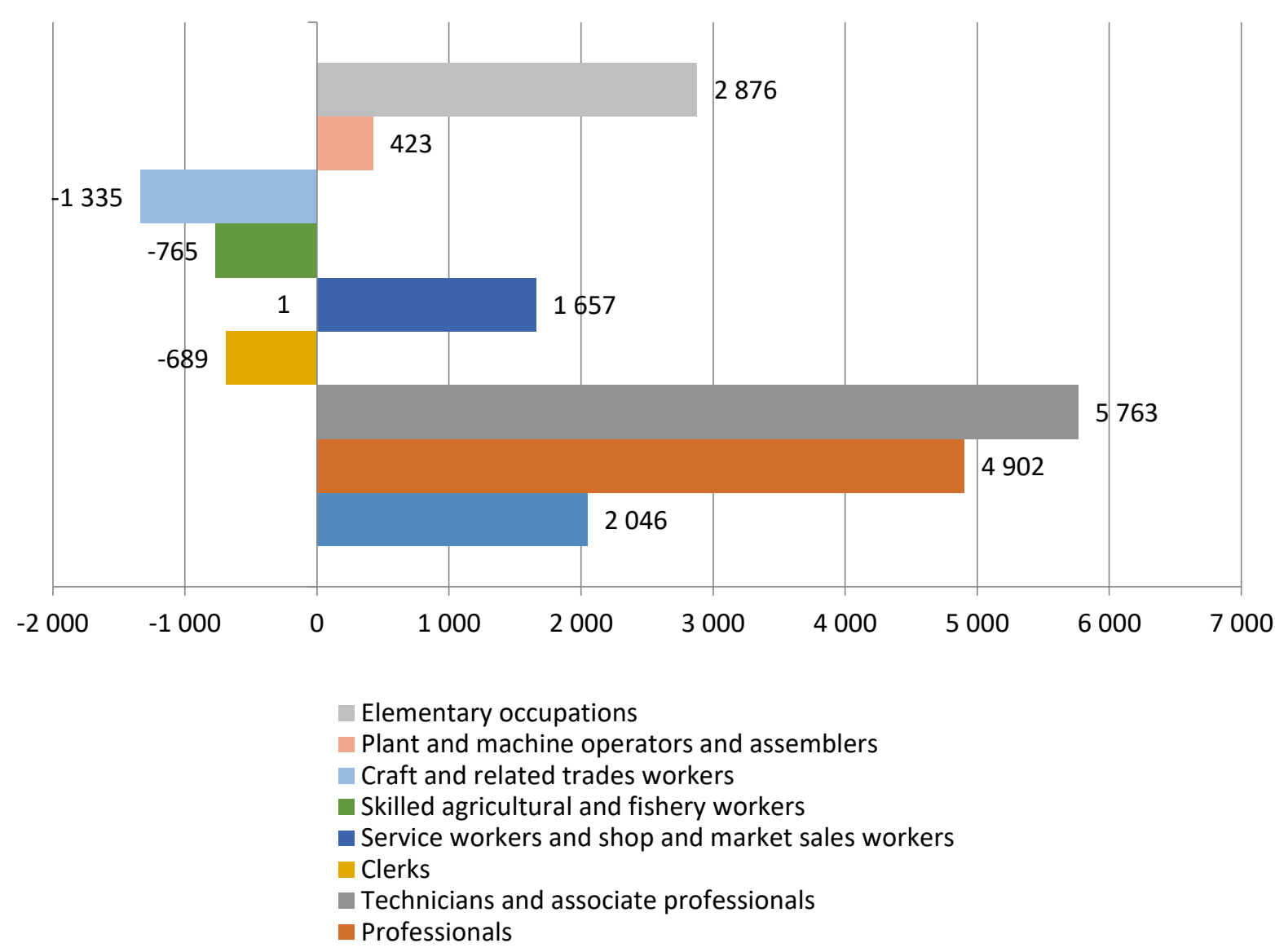

Figure 6. The Projected Change by Broad Occupation for the EU Countries, 2016-2030, Thousands

Source: (Cedefop, 2018).

Though, technological change and globalization may improve work-life balance and create new opportunities for a variety of groups to take an active part in the labor market, a better world of work cannot be guaranteed without the right policies and institutions in place (OECD, 2019). Investing in people's skills and competences is the factor of a country's and a company's success in the highly dynamic and competitive world. In order to ensure return on investments it is essential to anticipate which skills remain relevant and which new ones will be demanded in a short-, mid- and long-term perspective. The issue is essential to national and international debate (Cedefop, 2018). Thus, policies regarding education, economic development, and social protection should be developed along with the policies on public employment services and social protection, labor market regulation, taxation and even housing, transport, competition law and industrial policy (ILO, 2017). It is also important to involve social partners in national, sectoral and local governance arrangements, the design, monitor and evaluate education and training curricula, identify skills needed, assure quality etc. (European Commission, 2019b). State and private financial returns to tertiary education may be ensured 
only if curricula are of high quality, skills taught are demanded and there is a sufficient amount of jobs requiring high-level qualifications to avoid overload of overqualified job-seekers.

Taking all this into account, the Strategy for Reforming Higher Education in Ukraine until 2020 and the Strategy for Reforming Higher Education in Ukraine 2021-2031 underline the importance of focusing on graduates' qualifications required by the employers, involvement of employers and professional associations in decision-making in the sphere of education, fostering cooperation between educational establishments and enterprises, and introduction of the new forms of practice-oriented students' training, including dual education (MES, 2020b).

There have been a number of experiments worldwide aimed at the adaptation of the dual education and dual studies in order to strengthen the link between the real economy and the education system (Graf et al., 2014). When it comes to the experiments on the level of tertiary education, the process becomes more complicated as, unlike the well-established dual VET («Duale Ausbildung»), there is an ongoing dialogue in the Federal Republic of Germany on the concept and models of dual studies («Duales Studium») (BiBB, 2017). Thus, a «copy-paste» approach does not work for the agents of positive change.

\section{Methodology}

In order to safeguard the relevance of the article to the demand of the national experiment on introducing the dual studies, a cabinet study of the earlier works on ensuring the acquisition of the combination of profound theoretical knowledge and relevant skills by the workforce, with a special focus on the experience of the Federal Republic of Germany and Ukraine, had been conducted before launching the research. Based on the information gathered, in July 2020, the authors compiled a questionnaire for the companies named as partners by the TEEs listed in the Order №1296 on Dual Studies Experiment issued by the Ministry of Education and Science of Ukraine. The list of such partner-companies is presented in the previous study conducted by one of the authors and devoted to the experience of the Ukrainian TEEs participating in the experiment. The questionnaire consists of 24 questions, 4 of which are aimed at gathering general information about the company-respondent and 20 multiplechoice and open questions aimed at receiving information on the cases of dual studies organization. The questionnaire was presented for a review to the representatives of the Federation of the Metallurgists of Ukraine, HR union and education experts. In July-August 2020, the in-depth interviews were conducted by the researchers among the respondents from an overall sample. The data were analyzed and presented in a report in September 2020.

Thus, the method applied is the case-study, which allowed gathering the detailed data on the experience of the Ukraine-based companies introducing the dual studies. Due to the relatively small sample the universal coverage was chosen - 109 companies named by the TEEs indicated in the Ministry of Education and Science Order No. 1296. However, the study results are based on the answers of 55 companies (Table 1). 
Table 1. The Final Sample Formation

\begin{tabular}{cccc}
\hline $\begin{array}{c}\text { Number of companies } \\
\text { named by the TEEs as } \\
\text { partners }\end{array}$ & $\begin{array}{c}\text { Companies not } \\
\text { reached by the } \\
\text { researchers }\end{array}$ & Invalid answers & Valid answers \\
\hline 109 & 16 & 38 & 55 \\
\hline
\end{tabular}

Source: developed by the authors.

Companies were not reached by the researchers because TEEs provided no or incorrect contact information. The invalid answers included the answers of companies that terminated their activities, planned but did not introduce DS in 2019-2020 (mainly due to the COVID-19 pandemic) or did not know about their participation in the experiment.

The answers were provided by people responsible for dual studies in the companies or their directors. The following hypothesis has been tested: dual studies may be adapted to the Ukrainian national context, but it requires change of employers' understanding of their role in education.

\section{Results}

The non-response rate is 0.25 ; the valid response rate is 0.51 . Among 55 companies respondents in the framework of the survey - 26 are representatives of big business, 20 - of medium business and 9 small businesses. The overall number of students reported being dual students trained by the companies accounts for 481.22 companies train 1-2 students each; 19 companies - 3-9 students; 8 companies - 10-19 students; 6 companies - over 20 students each.

29 companies initiated cooperation with the TEEs in the framework of the experiment, while 26 respondents accepted the proposal of the pre-tertiary and tertiary educational establishments (Figure 7).

Other motives included the awareness of the positive experience of German companies, viewing DS as a development of existing cooperation, desire to ensure quality education of employees etc. According to the statements of some respondents, they realize that companies located in smaller cities, especially villages, or less economically developed regions have to compete with the employees from more advanced regions, bigger cities, especially the capital, or other countries. 


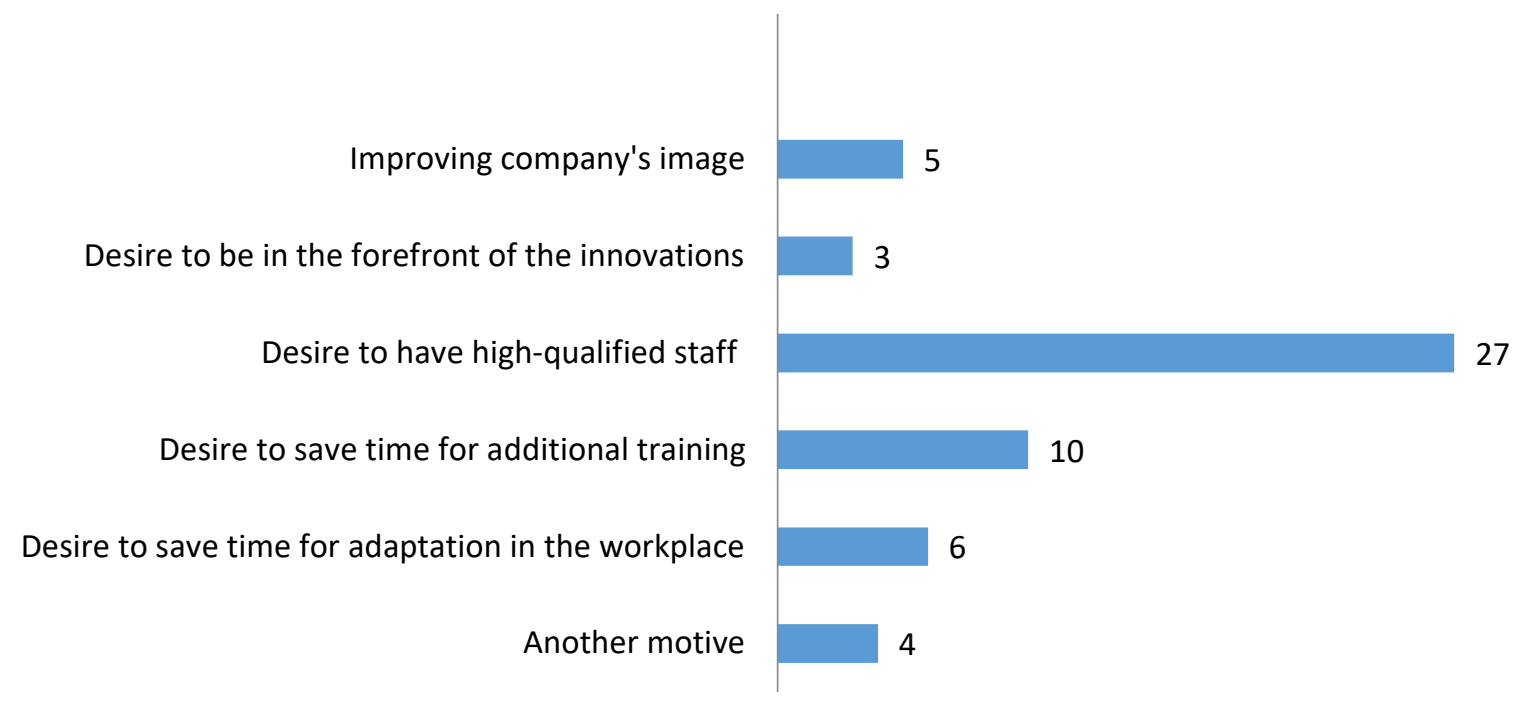

Figure 7. Employers' Motivation to Introduce Dual Studies

Source: developed by the authors.

As for the establishment of the partnerships, some are based on the long-term cooperation in the framework of internships/practical training organization. Apart from the specialties and the cooperation tested by time; employers try to pick TEEs located not far from the company's facilities. This allows them to save funds for students' travel and accommodation, with the exception of companies needing graduates of rare specialties like an aircraft designer. The prestige of TEEs also influences the decision of employers, when choosing partners for cooperation (Figure 8).

Work of relevant department/specialty in a HEE

Previous long-lasting cooperation with a HEE

Location (same region)

Initiative of a $\mathrm{HEE}$

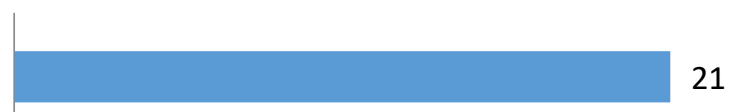

11

Figure 8. The Criteria for Choosing Partner-TEEs

Source: developed by the authors. 
48 companies indicated that they have a cooperation coordinator: in 45 cases this is a specially assigned person, in 3 cases - an employee who also works at a TEE. Most often the assigned persons are the heads of personnel departments, HR specialists, personnel training department representatives, or even deputy directors or directors. The last two options are typical of small businesses. Among 7 companies, which have no coordinators, 3 communicate with partner TEE through students.

12 companies communicate with educational establishments on a monthly basis, 6 organize discussions more often.

Not all the respondents confirmed meeting the existing formal requirements to the documentation of the DS partnerships. 42 companies signed bilateral cooperation agreements with TEEs and only 13 have trilateral agreements between a TEE, a company and a student. Most of the employers base their work on bilateral agreements with educational establishments and work-contracts with students.

30 companies said they do not influence the content of educational programs or students' individual education plans. The most common reasons for the lack of such influence are as follows: "not interested", "fully trust the TEE", "never knew we could", "we do not care what happens in the classroom, we will learn everything in the workplace" etc.

43 companies elaborated the selection procedure, while 12 respondents stated they accept all the students interested in dual studies. The selection procedure also includes selection criteria. The most significant criterion is the recommendation of a TEE (24 responses). The other criteria are the students' academic achievements, successful interview or test organized by the company, as well as the desire of the staff to pursue higher education.

Among the 55 company-respondents 16 have stated that they have no tutors, 4 of which do not even know they need to have one. 27 companies provide 1 tutor for the whole period of dual studies; 7 have 2-3 tutors per student for the whole period of the in-company training; and 5 companies state they foresee the work of more than 3 tutors. The last two cases allow rotation of students in different departments during the in-company training. More than a half of the respondents state that the tutors have received special training on methodological and psychological aspects of student training. 27 companies introduced mechanisms of tutor motivation, though their fees did not exceed 30 Euro per month. There are also quarterly or annual bonuses, additional vocation days or fully-covered vocations. At the same time, 12 respondents mentioned that they did not pay for tutorship as "employees get moral satisfaction" from transferring the knowledge to the younger generation.

As for the dual education models, the two most popular analogues of German models are the one with the integrated practical training and the one with the integrated professional training. The first one is foreseen for those who receive first higher education and have no professional background or qualification, while the second model is applied for training of persons with some qualifications/degree. In the framework of the model with the integrated 
practical training most students shift to the dual form of education on the 3rd or 4th year of the bachelor program or the 1st year of the master program.

According to the needs of the company, specific features of training on some specialties (seasonal works), as well as the distance between the facilities and a TEE, the parties choose the model of schedule formation - a divided day model, a divided week model, a block model (several weeks or months) etc. Unfortunately, there are cases, when students work full-time without breaks for academic education. Such approach breaches formal demands to organizing dual studies (Figure 9).

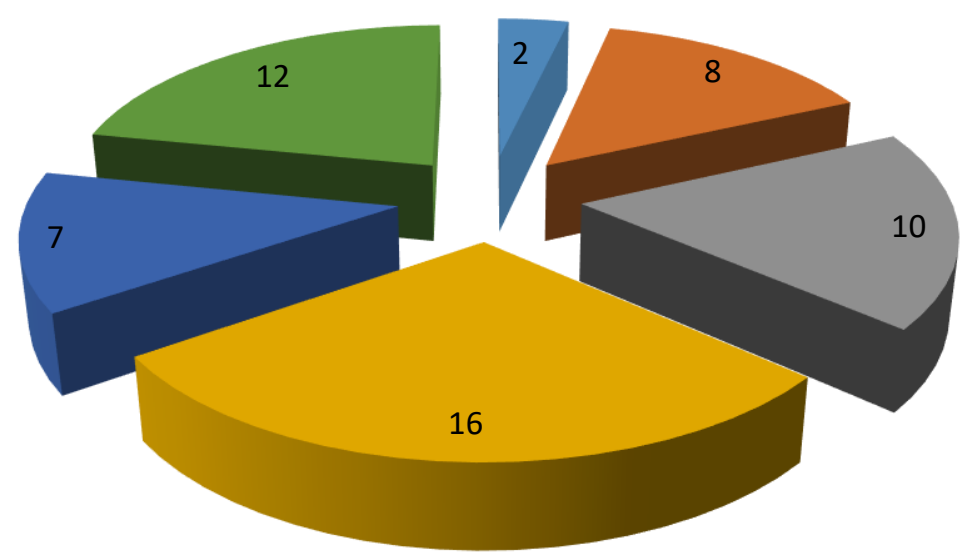

- Hard to tell

- Share of $50 \%$

Share of $50-70 \%$

- Share of $70-80 \%$

Share of $80-90 \%$

Share of $100 \%$

Figure 9. The Share of the In-Company Training in the Education Program Source: developed by the authors.

The Law of Ukraine "On Higher Education" indicates a clear delta of ECTS credits that should be foreseen for the in-company training.

Table 2. The Amount of Credits for the In-Company Training that Qualify a Program as Dual According to the Ukrainian Legislation.

\begin{tabular}{ccc}
\hline Education Level & $\begin{array}{c}\text { Minimum Amount of Credits } \\
(25 \%)\end{array}$ & $\begin{array}{c}\text { Maximum Amount of Credits } \\
(60 \%)\end{array}$ \\
\hline Junior bachelor (240 credits) & 60 & 144 \\
\hline Junior bachelor (160 credits) & 40 & 96 \\
\hline Bachelor (240 credits) & 60 & 144 \\
\hline Master (90 credits) & 23 & 54 \\
\hline Master (120 credits) & 30 & 72 \\
\hline
\end{tabular}

Source: An analytical report on the first-year results of the experiment on introducing dual studies in the pretertiary and tertiary educational establishments. 
Only 4 companies have a formula for calculating costs of the in-company training of one dual student and only a few calculated such costs approximately. All the companies named salary as the main budget line when it comes to dual students. 10 respondents additionally cover transportation costs, meals and accommodation, when needed. The costs for accommodation are mostly covered by the remotely located companies or when due to the need in students of rare specialties a company partners with a TEE located over a $100 \mathrm{~km}$ away. Some respondents also offer the so-called "scholarships" in addition to salaries. The formulas additionally include payments to tutors, costs of the uniform for dual students and consumables. One more and least popular budget line is costs of studies in a TEE. Only 7 employers are ready to cover such costs of students getting education in private educational establishments or in state TEEs but on a contractual basis. 28 respondents mentioned they are not ready to cover such costs as they are not sure a student would stay in the company after graduation. There are no official mechanisms of obliging students to continue working for a company after graduation, thus, especially in the times of economic instability such investments are seen as highly risky.

By the end of the first year of the experiment, 6 cases of terminating company-student cooperation have been reported, 5 of which are caused by the Corona-crisis and 1 - by student's violations of obligations.

There are also 16 cases when termination of such cooperation was initiated by students. Two main reasons for taking such decisions were a desire to change the major and a gap between students' expectations and the working life reality. The number of such cases may be reduced if the selection procedure is improved or in some cases at least applied. One more worrisome reason was mentioned: "a hardship for women to adapt to a men's team". The analysis of the reasons behind such a statement is beyond the scope of this article; yet such cases must be eliminated from the very start of DS introduction.

Employers emphasize that one of the pervasive problems causing the poor quality of a "product" released by TEEs to the labor market is a low level of teachers' practical training and lack of access to modern technologies. Thus, 30 respondents are ready to open their doors for training TEE teaching faculty, though only 18 actually do so. The situation is explained by the teachers' unwillingness to raise their qualifications, as employers see it.

As for the obstacles and challenges, the respondents have indicated the following:

- a lack of established and widely-accepted national philosophy of dual studies and the principles of cooperation between the parties;

- a need to enroll dual students in a position that corresponds to their qualification level. This is not an issue when applicants have already obtained a certain qualification, graduated from a vocational education institution or are getting their master degree;

- low motivation of educational institutions to introduce DS as university administrations and teaching staff are afraid of the workload reduction due to the bigger share of credits foreseen for the in-company training; 
- employers' concerns that their investments in a dual student will not return or, even worse, their competitors will benefit from such investments into future workforce. Current norms do not oblige graduates to work at the company for some period of time after graduation, thus, ex-dual student may shift to a different company in Ukraine or abroad. Even when domestic companies offer competitive salaries, the overall infrastructures of Ukrainian cities, as well as political and economic climate, reinforce labor migration. Moreover, national producers cannot compete with the trans-national companies, when it comes not only to remuneration, but to other benefits as well.

- a lack of the employers' willingness to deal with all bureaucratic nuances that educational institutions are required to adhere to. They noted that paperwork could be a reason for terminating the existing cooperation or non-participation in DS development in the future, because it requires too many person-hours.

Nevertheless, all 55 companies view dual studies as a positive development with great potential. Thought, 11 respondents emphasized that it should not be considered a panacea, rather a modern tool of advancing competitiveness of a student, a company and a national economy as a whole.

\section{Conclusions}

The survey results demonstrate that some Ukraine-based employers feel the need in cooperating with educational establishments; and for many of them, especially those located in the regions, this is not even the matter of ensuring company's leading positions on the market, but rather a survival. Labor migration, trans-national corporations, poor infrastructure of many Ukrainian cities, towns and villages lead to the drain of the most talented and skilled. In addition to that, "severe hunger" for qualified work force that meets the employers' expectations is caused, among other factors, by the lack of educational programs' modernization and poor connection of education and business. In the framework of the interviews employers underlined that for decades those had been the factors defining the development of the Ukrainian education, which turned into self-serving industry of issuing diplomas. However, despite recognizing the problem, many discussions and the instruments and norms of the legislation available for many years, the cooperation of TEEs and business used to be mostly faked and dealt with as a formality rather than an opportunity (with rare exceptions).

The FES-Ukraine project aimed at presenting and adapting the German models of dual studies that was launched in 2013 and engaged a wide circle of stakeholders, including the Ministry of Education and Science of Ukraine, contributed to the education reform and helped to establish or re-launch TEEs-business cooperation. It is too early to talk about a dual studies system yet, as there are too many elements still missing, like the active role of the Chambers of Trade and Commerce, local self-government, regional unions of employers, or even a widely accepted clear philosophy or finalized rules of parties' cooperation. Failure to meet the already established formal requirements to the DS organization such as the amount of credits (25$60 \%)$ envisaged for the in-company training, ensuring the work of a tutor, bilateral and 
trilateral agreements and others demonstrate the insufficient understanding by both educational institutions and employers of the content and features of the dual form of education. Entrepreneurs emphasized the need in the awareness rising campaign and methodological materials, as well as additional explanatory work to clarify the difference between work, practice, distance learning, evening and dual forms of education.

Yet DS is already included in the legislation and defined as a form of education, and the process of establishing a mechanism of the dual studies implementation is being tested within the national experiment to be conducted in the period of 2019-2023. However, Ukraine-based employers already see the DS advantages (see Table 3 ).

Table 3. DS Advantages According to the Employers

\begin{tabular}{|c|c|c|}
\hline For employers & For students & $\begin{array}{l}\text { For higher educational } \\
\text { establishments }\end{array}$ \\
\hline $\begin{array}{l}\text { Saving funds for training } \\
\text { employees. }\end{array}$ & $\begin{array}{l}\text { Possibility to learn about the } \\
\text { specific features of a particular } \\
\text { production and corporate culture } \\
\text { for more informed career choices. }\end{array}$ & $\begin{array}{l}\text { Possibility to modernize the } \\
\text { content of education programs } \\
\text { due to communication with } \\
\text { employers. }\end{array}$ \\
\hline $\begin{array}{l}\text { Saving time for adaptation of } \\
\text { young specialists and staff } \\
\text { training. }\end{array}$ & $\begin{array}{l}\text { Possibility to study based on real } \\
\text { cases and to have access to latest } \\
\text { technologies. }\end{array}$ & $\begin{array}{c}\text { Advancing qualification level of } \\
\text { the teaching staff and access to } \\
\text { new technologies. }\end{array}$ \\
\hline $\begin{array}{l}\text { Possibility to enroll the most } \\
\text { motivated and talented } \\
\text { graduates for the benefit of the } \\
\text { company. }\end{array}$ & $\begin{array}{l}\text { Due to rotation possibility to make } \\
\text { better choices as of specialization. }\end{array}$ & \multirow{3}{*}{$\begin{array}{l}\text { Improving the image and } \\
\text { attracting applicants' attention }\end{array}$} \\
\hline \multirow{2}{*}{$\begin{array}{l}\text { Overcoming the challenge of } \\
\text { finding qualified staff, especially } \\
\text { in the regions. }\end{array}$} & $\begin{array}{c}\text { Financial support (salary, benefits, } \\
\text { etc.). }\end{array}$ & \\
\hline & $\begin{array}{l}\text { Advancing one's competitiveness } \\
\text { on the labor market. }\end{array}$ & \\
\hline
\end{tabular}

Source: developed by the authors.

Though, as of today only 55 companies are actively participating in the experiment, while more than a hundred are indicated in the MES Order \#1296, the interest to dual studies is generally high. The three most widespread reasons preventing companies to open their doors for dual students are the cautious position of TEEs due to the motives discussed above and a desire to learn on others' mistakes, worsening of the economic situation and interruption of the operation processes because of the quarantine caused by the COVID-19 pandemic and lack of all necessary normative framework.

For the most of the companies interviewed the openness of a TEE for real (not formal) cooperation was the prerequisite for establishing cooperation and partnership in the 
framework of the experiment; while the main motive was a desire to get a highly-qualified labor force.

The variety of the companies interested in DS should be noted. These are enterprises of different forms of ownership located in all regions of Ukraine, except the occupied territories, representing different sectors of the economy - mining, metallurgical and food industries, engineering, agriculture, energy, transport, IT, finances etc. IT sector requires special attention as some specific challenges in DS introduction have been identified, which require additional study given the potential of this sector.

In the first year of the experiment, it was employers who often initiated cooperation with educational institutions. First of all, these are enterprises that need specialists with technical qualifications. Sometimes, an employer has no alternative at all when choosing a partner, because only one or two educational institutions have a respective faculty (for example, when it comes to the aerospace or mining industry). In turn, such a narrow focus determines mutual interest, promotes long-term cooperation that emerges between large enterprises and narrow-profile educational institutions. This close cooperation often determined the student selection procedure. In such cases, the recommendation of the educational institution played a crucial role. However, employers should pay more attention to forming their own opinions based on tests or personal interviews conducted by a company itself. The lack of well-tailored selection procedure leads to early termination of contract relationships with the students.

Technical majors like "Mechanical Engineering", "Electrical Engineering" and "Agricultural Sciences and Food" were the most demanded. During 2019-2020 academic year 17 companies trained 52 DS students studying economics and social sciences, while 38 enterprises provided places for 467 students of technical specialties.

Currently in Ukraine there are no mechanisms to oblige applicants to work at the company after graduation. Therefore, employers are concerned about their investments in the students who after graduation may choose to work for a competitor. Yet most interviewed employers note that they have not calculated the cost of training yet.

Regarding the employer's participation (influence) in shaping the content of education, the organization of educational process or choosing the topic of students' research activities, almost half of the employers do not participate in these processes due to distrust in relations with TEEs on this matter. In their turn, not all the respondents are ready to provide opportunities for TEE teaching staff to develop their professional qualifications using their facilities. But even more often the staff is not interested in professional development of the kind.

As a result of the study, a number of problems were identified. According to the employers, not all educational institutions are able to provide a sufficient level of education; not all TEEs agree to provide enterprises with the powers foreseen in the normative documents regarding DS or to develop new educational/training programs. They do not always explain to employers 
that the dual nature of this form of education is provided by combining two places of study, namely, educational institutions and enterprises. In this case, there are significant differences in the perception of DS and expectations.

Among the obstacles to the fast spread of DS in Ukraine employers named the following:

- instability of the political situation in the country and the overall state of the economy;

- a lack of the finalized normative framework;

- a lack of state financial support or tax cuts;

- the overall poor state of the national education system and especially the low level of students' knowledge and skills;

- additional financial and time costs required;

- a lack of mechanisms to oblige a student to stay with a company after graduation and high level of labor migration;

- students' unrealistic expectations from work;

- a lack of capacities to train tutors, etc.

In general, the dual studies implementation has revived the dialogue between educational institutions and employers, because, unlike workplacement and distance learning, the DS creates better conditions for establishing parity, finding compromises and meeting the needs of all parties. In order to strengthen public-private partnerships in the field of education and to avoid confusion when it comes to the DS, a comprehensive information campaign should be launched. Special programs for training tutors would also be helpful. Moreover, the normative framework should be finally formed and methodological and information materials should be elaborated, which would help decrease the tension. In addition, it is advisable to read the study of dual students' experience, which provides another perspective of the issue.

A gender aspect of introducing DS should also be studied more carefully, as in the first year of the experiment less than third of all the dual students were female, and respondents also mentioned that "it might be hard for a girl to fit in a men's team", which should be a red flag for a TEE when looking for partners.

The results support the suggestion that dual studies are adaptable to the Ukrainian national context, but this requires a flexible approach and change of employers' mentality as of stateprivate partnership in the sphere of education. The results presented are the milestone for introducing DS in Ukraine and might become a factor of the youth unemployment rate drop and economic development in the long run.

\section{Acknowledgements}

The authors are grateful to the Ministry of Education and Science of Ukraine, all the companies, TEEs, students and other enthusiasts, who invest their time and effort into introducing DS and share their experience in the framework of the experiment. 


\section{References}

Bakhshi, H., Downing, J., Osborne, M., \& Schneider, P. (2017). The Future of Skills: Employment in 2030. London: Pearson and Nesta. Retrieved from https://futureskills.pearson.com/research/assets/pdfs/technical-report.pdf

Buchynska, O., Chaikovska, A., Davlikanova, O., \& Lylyk, I. (2020). Dual Form of Education in Pre-tertiary and Tertiary Educational Establishments: Employers' Perspective. Ukraine: FES. Retrieved from https://mon.gov.ua/ua/news/dualna-forma-zdobuttya-osviti-u-zakladah-vishoyi-ta-fahovoyiperedvishoyi-osviti-ochima-robotodavciv

Bundesinstitut für Berufsbildung. (2017). Empfehlung des Hauptausschusses des Bundesinstituts für Berufsbildung vom 21. Juni 2017 zum dualen Studium. Retrieved from https://www.bibb.de/dokumente/pdf/HA169.pdf

Bundesinstitut für Berufsbildung. (2020). Duales Studium in Zahlen 2019. Retrieved from http://www.bibb.de/veroeffentlichungen

Bundesinstitut für Berufsbildung. (2020a). BIBB-report Heft 1: Ausbildung in Deutschland, Investition gegen Fachkraeftemangel, Mai 2020. Retrieved from http://www.bibb.de/veroeffentlichungen

Card, D., \& DiNardo, J.E. (2002). Skill-Biased Technological Change and Rising Wage Inequality: Some Problems and Puzzles. Journal of Labor Economics, 20(4), 733-783. Retrieved from https://davidcard.berkeley.edu/papers/skill-tech-change.pdf

Cedefop. (2012). Preventing Skill Obsolescence - Rapid Labor Market Changes Leave Too Many Workers at Risk of Losing Their Skills. Briefing Note. Retrieved from https://www.cedefop.europa.eu/files/9070_en.pdf

Cedefop. (2013). Roads to Recovery: Three Skill and Labor Market Scenarios for 2025. Briefing Note. Retrieved from https://www.cedefop.europa.eu/files/9081_en.pdf

Cedefop. (2016). Future Skill Needs in Europe: Critical Labor Force Trends. Luxembourg: Publications Office. http://dx.doi.org/ 10.2801/56396

Cedefop, Eurofound. (2018). Skills Forecast: Trends and Challenges to 2030. Luxembourg: Publications Office. Retrieved from http://data.europa.eu/doi/10.2801/4492

Chaikovska, A., Davlikanova, O., \& Ischenko, T. (2020). Analytical Report on the Results of the First Year of the Experiment on the Dual Studies Introduction in the Pre-Tertiary and Tertiary Educational Establishments. Ukraine: FES. Retrieved from https://mon.gov.ua/storage/app/media/rizne/2020/09/28/zvitza20192020nr shchodorealizatsiyidualnohonavchannya.pdf

Chism, S., Holder, T., Keuss, T., \& Small, N. (2016). College Student Retention and Persistence Retention and Persistence in Higher Education: An Exploratory Study of Risk Factors and Milestones Impacting Second Semester Retention of Freshmen Students. College Student Retention and Persistence. Retrieved from https://independent.academia.edu/UMSLTutoring 
Council of the European Union. (2009). Strategic Framework for European Cooperation in Education and Training. Retrieved from https://eur-lex.europa.eu/legalcontent/EN/TXT/PDF/?uri=CELEX:52009XG0528(01)\&from=EN

Dachs, B. (2013). The Impact of New Technologies on the Labor Market and the Social Economy. European Parliamentary Research Services. Retrieved from https://www.europarl.europa.eu/RegData/etudes/STUD/2018/614539/EPRS_ STU(2018)614539_EN.pdf

Dolphin, T. (Ed). (2015). Technology, Globalisation and the Future of Work in Europe: Essays on Employment in a Digitised Economy, IPPR. Retrieved from http://www.ippr.org/publications/technology-globalisation-and-the-futureof-work-in-europe

European Commission. (2019). Towards a Sustainable Europe by 2030. Reflection Paper. Retrieved from https://ec.europa.eu/commission/sites/betapolitical/files/factsheets_sustainable_europe_012019_v3.pdf

European Commission. (2019). Reflection Paper Towards a Sustainable Europe by 2030. Retrieved from https://op.europa.eu/en/publication-detail/-/publication/3b096b37-300a-11e9-8d0401aa75ed71a1/language-en/format-PDF

Graf, L. (2015). Germany: Stability and Change. Education in the European Union: Pre-2003 Member States. London: Bloomsbury Publishing. Retrieved from https://chart.googleapis.com/chart?chs=400x400\&cht=qr\&chl=https://books.google.com.ua/bo oks?id=0_nrBQAAQBAJ\&source=qrcode

Graf, L., Powell, J. J., Fortwengel, J., \& Bernhard, N. (2014). Dual Study Programmes in Global Context: Internationalisation in Germany and Transfer to Brazil, France, Qatar, Mexico and the US. Bonn, Germany: DAAD.

Haskel, J.E., \& Slaughter, M.J. (2002). Does the Sector Bias of Skill-biased Technical Change Explain Changing Skill Premia? European Economic Review, 46(10), 1757-1783. Retrieved from https://www.sciencedirect.com/science/article/abs/pii/S0014292101001854

Hermann, K. (2020). How to Find the Right Dual Study Program. Hamburg, Germany: Spiegel. Retrieved from https://www.spiegel.de/start/duales-studium-so-finden-sie-den-passenden-studiengang-a4aaeab3e-103a-4b10-85a1-

2eaac90ea6d8?sara_ecid=soci_upd_wbMbjhOSvVilSjc8RPU89NcCvt|FcJ

Heyman, F., \& Sjöholm, F. (2019). Globalization, Job Tasks and the Demand for Different Occupations. Open Edition journals, 67-92. https://doi.org/10.4000/travailemploi.8962

Hippach-Schneider, U., Schneider, V., Ménard, B., \& Tritscher-Archan, S. (2017). The Underestimated Relevance and Value of Vocational Education in Tertiary Education - Making the Invisible Visible, $\begin{array}{llll}\text { Journal of Vocational Education \& Training, 69(1), 28-46. } & \text {. }\end{array}$ http://dx.doi.org/10.1080/13636820.2017.1281342 
ILO. (2017). Global Employment Trends for Youth 2017: Paths to a Better Working Future. International Labor Office. Geneva: ILO. Retrieved from https://www.ilo.org/wcmsp5/groups/public/--dgreports/---dcomm/---publ/documents/publication/wcms_598669.pdf

ILO. (2020). Global Employment Trends for Youth 2020: Technology and the Future of Jobs International Labor Office. Geneva: ILO. Retrieved from https://www.ilo.org/wcmsp5/groups/public/--dgreports/---dcomm/---publ/documents/publication/wcms_737648.pdf

ILO, OECD. (2018). Global Skills Trends, Training Needs and Lifelong Learning Strategies for the Future of Work. Report prepared by the ILO and OECD for the G2O Employment Working Group. Retrieved from https://www.ilo.org/wcmsp5/groups/public/---dgreports/--inst/documents/publication/wcms_646038.pdf

Kaufman, H. (1974). Obsolescence \& Professional Career Development. New York: American Management Association.

OECD. (2008). Tertiary Education for the Knowledge Society: Summary in German. Paris: OECD

OECD. (2019). The Future of Work. Employment Outlook 2019. Retrieved from https://www.oecd.org/employment/Employment-Outlook-2019-Highlight-EN.pdf

State Statistic Service. (2020). The Level of Unemployment in Ukraine. Retrieved from http://www.ukrstat.gov.ua/operativ/operativ2006/rp/ean/ean_u/arh_rbrn_u.htm

The Ministry of Education and Science of Ukraine. (2016). The Strategy of the Higher Education Reformation in Ukraine till 2020.2 Retrieved from https://mon.gov.ua/storage/app/media/gromadske-obgovorennya/2016/18-strategiyareformuvannya-vishhoi-osviti-20.doc

The Ministry of Education and Science of Ukraine. (2020). The Draft Strategy of the Higher Education Reformation in Ukraine 2021-2031. Retrieved from https://mon.gov.ua/storage/app/media/rizne/2020/09/25/rozvitku-vishchoi-osviti-v-ukraini-0210-2020.pdf

The Ministry of Education and Science of Ukraine. (2020). The Strategy of Higher Education Development 2021-2031. Retrieved from https://mon.gov.ua/storage/app/media/rizne/2020/09/25/rozvitku-vishchoi-osviti-v-ukraini-0210-2020.pdf

Tkachenko, V., Kuzior, A., \& Kwilinski, A. (2019). Introduction of Artificial Intelligence Tools into the Training Methods of Entrepreneurship Activities. Journal of Entrepreneurship Education, 22(6), 110.

Wissenschaftsrat. (2013). Empfehlungen zur Entwicklung des dualen Studiums: Positionspapier. [Recommendations on the Development of Dual Study Programmes: Position Paper]. Berlin: Wissenschaftsrat.

Verkhovna Rada of Ukraine. (2019). The Law of Ukraine "On Higher Education" No. 392-IX as of 18.12.2019. Retrieved from https://zakon.rada.gov.ua/laws/show/1556-18 
World Bank. (2002). Constructing Knowledge Societies: New Challenges for Tertiary Education. Retrieved from https://openknowledge.worldbank.org/bitstream/handle/10986/15224/2497 30PUBOREPLOOKnowledgeOSocieties.pdf 